\title{
Against Root Faithfulness in Cupeño Stress
}

\author{
Anthony D. Yates \\ University of California, Los Angeles
}

\section{Introduction}

The word-level stress system of Cupeño (Takic, Uto-Aztecan) has attracted theoretical and typological interest since the pioneering work of Hill \& Hill (1968), who established the basic principles of this system: the single primary stress is preferentially assigned to a morpheme that is lexically pre-specified for prominence, else to the word's leftmost syllable (cf. Crowhurst 1994 Alderete 1999 2001a|b. Attraction of stress to a stress-preferring morpheme - an abstract lexical feature referred to here as ACCENT - can be observed in $(1 \mathrm{l}-\mathrm{c})$, while $(1 \mathrm{l})$ shows the emergence of word-initial stress in the absence of accented morphemes $\unlhd^{1}$
a. $/ \sqrt{ }$ nəyú - wənə/ $\rightarrow$ [nəyú-wənə]
'have-CUST.PL'
b. $/ \sqrt{ }$ ใámu - wənə/ $\rightarrow$ [?ámu-wənə]
c. / / yax- qá/ $\rightarrow$ [ya-qá?]
'hunt-CUST.PL'
d. $/ \sqrt{ }$ yax - wənə/ $\rightarrow$ [yáx-wənə]
'say-PRS.SG'
e. / / nəyú - qá/
$\rightarrow$ [nəyú-qa $]$
'say-CUST.PL'
'have-PRS.SG'

The crux of this paper is the stress pattern in 11e). Alderete (1999 2001a b argues that Cupeño has ROOT-CONTROLLED ACCENT (RCA): stress is assigned to the root in examples like (1) because the lexically specified accent of the root $(/ \sqrt{ }$ nəyú/) takes precedence over the accent of the affix $(/$-qá $/)$. Within Optimality Theory (Prince \& Smolensky, 1993/2004), Alderete interprets this "root dominant" stress pattern as an effect of the privileged status of faithfulness relations in roots relative to other morphemes (McCarthy \& Prince, 1995 1999 Beckman 1998) ${ }^{2}$ Yet while privileged root faithfulness has been well established for phonological processes such as vowel harmony and assimilation, Cupeño would be typologically exceptional among languages with lexical accent systems in requiring root faithfulness as an independent principle to account for the surface distribution of word stress (see 5.3 below).

This paper proposes an alternative, optimality-theoretic account of Cupeño stress assignment, termed here the LEFTMOST (LM) analysis. I argue that stress is assigned to the root in examples like (1) because it is the leftmost accented morpheme, which optimally satisfies both the general prosodic faithfulness constraints responsible for assigning stress to accented morphemes in (1a-c), and the markedness constraint(s) driving left-edge word stress in (1 d). I contend that the LM analysis provides an account of the Cupeño data that is more economical, more typologically natural, and empirically superior to the RCA analysis.

The remainder of this article is structured as follows. Section 2 introduces the primary data and the core constraints relevant to the LM analysis; these constraints are then applied to derive the major generalizations about Cupeño word stress. Sections 34 examine word stress in two prefixing contexts,

\footnotetext{
* Earlier versions of this paper were presented at the UCLA Phonology and American Indian Linguistics Seminars; I am grateful to these audiences, as well as the participants of AMP 2016, for stimulating discussion. Special thanks are also due to Jesse Lundquist, Craig Melchert, Ryan Sandell, Sam Zukoff, and especially, Pamela Munro for their critical feedback and positive encouragement. Any remaining errors are of course my own responsibility.

${ }^{1}$ All primary data cited here is from Hill \& Nolasquez (1973) and Hill 2005). Cupeño forms are given in IPA transcription except that I employ [y] for standard $[\mathrm{j}]$ and use acute $\left(^{\prime}\right)$ to mark accent(s) in URs $(/ \dot{x} /)$ and primary stress in SRs ([x́]). In addition, roots are indicated in URs with “ $\sqrt{ }$ " (i.e. $/ \sqrt{ } \mathrm{x} /$ ), and "=" marks clitic boundaries.

2 This relationship is formalized by McCarthy \& Prince (1995) as a meta-constraint on constraint rankings: RooT FAITH $\gg$ AFFIX FAITH.

(C) 2017 Anthony D. Yates

Proceedings of AMP 2016
} 
where both the assumptions and the predictions of the LM and RCA analyses diverge; it is shown that the LM analysis correctly predicts word stress in all prefixed words, whereas the RCA analysis cannot generate observed stress patterns in the reduplicated forms discussed in section 4 . Section 5 summarizes arguments in support of LM (and against RCA), and discusses the implications of this reanalysis of Cupeño word stress for the typology of lexical accent systems.

\section{Toward an analysis of Cupeño stress}

2.1 (Analyzing) lexical accent in Cupeño Word stress in Cupeño - an extinct Uto-Aztecan language previously spoken in southern California (Hill 2005 cf. Golla|2011) — is FREE, CULMINATIVE, OBLIGATORY, and UNBOUNDED (Hyman 2006 van der Hulst2014 i.a.). Every word bears a single primary stress, realized principally by increased duration and intensity of the stressed syllable ${ }^{3}$ Stress typically falls within the first three syllables of the word, most frequently on the initial syllable of the root, but second syllable root stress is common. In addition, a few longer words have stress on the third syllable of the root or later, which suggests that there are no window restrictions on word stress ${ }^{4}$ Any syllable of a word may therefore be stressed, but which syllable bears stress cannot be predicted on the basis of purely phonological factors (e.g. syllable weight, metrical structure), as is clear from the near-minimal pairs in 22):

\begin{tabular}{|c|c|c|c|c|}
\hline [háxa-1] & 'sand-ABSL' & vs. & [kaxá-1] & 'valley quail-ABSL' \\
\hline [tfála-1] & 'bark-ABSL' & & [malá-1] & 'metate-ABSL' \\
\hline [şáwi-f] & 'bread-ABSL' & & [kawí-J] & 'rock-ABSL' \\
\hline [?ámu-wənə] & 'hunt-CUST.PL' & & [nəџú-wənə] & 'have-CUST.PL' \\
\hline [nó-təw] & '1SG-see' & & [nə-páw] & '1SG-friend' \\
\hline [pə-pá-qal] & '3SG-drink-PST.IPFV.SG' & & [pə-ya-qál] & '3SG-say-PST.IPFV.S \\
\hline
\end{tabular}

Stress is instead attracted to certain morphemes, which are lexically marked as preferred hosts of prosodic prominence, i.e. accented. Disyllabic morphemes may be accented on either syllable, which accounts (e.g.) for the contrast in 22a) between /háxa-l/ and /kaxá-1/. Accounting for the distribution of stress in word-prosodic systems of this kind — LEXICAL ACCENT (LA) systems (Revithiadou, 1999) — necessitates assuming faithfulness constraints that govern the relationship between underlying and surface prosodic prominence (i.e. between accent and stress); here, I adopt the set of constraints in (3) from the "Prosodic Faithfulness" family (Alderete 1999 et seq.), which treat prominence as an autosegmental feature and require corresponding strings to have the same featural value:
a. MAX-Prom: "A prominence in the input must have a correspondent in the output."
b. Dep-Prom: "A prominence in the output must have a correspondent in the input."
c. *FLOP-PROM: "Corresponding prominences must have corresponding sponsors and links." 5

High-ranking MaX-Prom ensures that, when a single accented morpheme is present in the input, stress will surface faithfully on its accented syllable. Yet because accent is an idiosyncratic lexical property of morphemes, it is possible that a word may contain several accented morphemes or, alternatively, none at all; in such cases, the faithfulness constraints in (3) interact with the undominated markedness constraint in (4), which enforces the requirement that every word in Cupeño has a single primary stress:

\footnotetext{
${ }^{3}$ It is generally held that Cupeño lacks secondary stress (cf. Alderete $2001 \mathrm{~b} 458$ n.4). Unstressed syllables also exhibit sub-phonological vowel reduction (described by Hill 2005 17-20), which is left unmarked here since it does not materially affect the analysis.

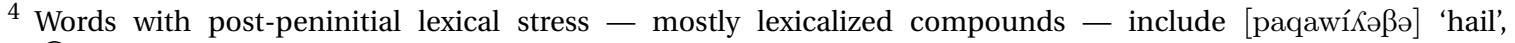
[kitfiməkúKimal] 'cumbersome' (Hill 2005 23-4; cf. Alderete 2001b 465 n.14).

5 *FLOP-PROM is required to prevent accentual "migration" (see further Alderete 2001a): it penalizes a hypothetical input-output pair like /babá/ $\rightarrow$ [bába], where initial stress and second syllable accent would stand in correspondence. Following Alderete 2001b, I assume this constraint is undominated in Cupeño and for simplicity, exclude candidates violating it from all tableaux. An output like [bába] is therefore analyzed here as involving both a deletion and an insertion of prominence (violating MAX-PROM and DEP-PROM respectively).
} 
(4) Culminativity (= Culm): "A prosodic word must have exactly one stressed syllable.” 6

Furthermore, LA systems have some (morpho)phonological principle(s) responsible for determining which of several accented morphemes are assigned stress, or in their absence, for assigning "default" stress to a prosodically optimal position. Under the LM analysis, both are effected by (5):

ALIGN-L(PK, $\omega)$ (= PK-L): “The left edge of every stressed syllable is aligned with the left edge of the word (evaluated gradiently; one violation per intervening syllable). 7

Like many fixed stress systems, Cupeño has a phonological preference for stress to coincide with the word's left edge. Yet unlike (e.g.) Hungarian ${ }^{8}$ where a constraint like 5 results in consistent word-initial primary stress, Cupeño has accented morphemes that override its left edge preference, attracting stress to non-initial syllables. (5) therefore emerges most clearly when a word lacks accented morphemes, causing stress to fall on the prosodically optimal word-initial syllable; in addition, the leftmost of multiple accents is assigned stress because it incurs the fewest violations of [5].

The interaction of the constraints in 345 is illustrated below, where the ranking in 6 is shown to correctly predict attested [nəyú-qa] 'have-PRS.SG' in the tableau in 7]:

Culminativity $\gg$ MAX-Prom, DEP-PrOM $\gg$ PK-L

\begin{tabular}{|cc||c|c:c|c|}
\hline \multicolumn{2}{|c|}{$/ \sqrt{ }$ nəyú - qá/ } & CUlm & MAX-Prom & DEP-Prom & PK-L \\
\hline \hline a. & nəyú-qá & $* !$ & & & $* * *$ \\
\hline b. & nəyú-qa & & $*$ & $*$ & $*$ \\
\hline c. & nəyu-qá? & & $*$ & $*$ & $* * !$ \\
\hline d. & nóyu-qa & & $* * !$ & $* !$ & \\
\hline
\end{tabular}

The faithful candidate $7 \mathrm{a}$ ) is ruled out by undominated CULMINATIVITY, which forces deletion of an accent in violation of MAX-PROM as in (7bc). The winning candidate $7 \mathrm{~b}$ ) is then preferred to $7 \mathrm{k}$ ) because it better satisfies lower-ranked PK-L. 77d) fares better than $7 \mathrm{~b}$ ) with respect to PK-L, but loses because it incurs an extra violation of higher-ranked MAX-PROM ${ }^{9}$

The principal Cupeño data is examined further in 2.2. where it is shown that the constraint ranking in 6] - the core of the LM analysis - successfully derives the major generalizations about stress assignment.

2.2 Core data \& generalizations The Cupeño root inventory is characterized by a binary opposition in accentual properties: accented vs. unaccented. Root accentedness is a synchronically arbitrary property 10 and therefore must be lexically listed individually. The majority of roots are accented on either the first or second sylllable, while a smaller set of roots - traditionally referred to as "stressless" (Hill \& Hill 1968 - are unaccented ${ }^{11}$ Some accented and unaccented roots are given in (8):

\footnotetext{
6 This constraint covers both the CULMINATIVE ("at most one stress") and OBLIGATORY ("at least one stress") properties discussed by Hyman 2006. It is the obligatoriness parameter that differentiates Cupeño from an LA system like Japanese, where words may surface without a primary prosodic prominence [Ito \& Mester 2016 i.a.).

7 The proposed analysis assumes gradient evaluation of alignment constraints. McCarthy (2003) has argued that such constraints are unnecessary and thus should be excluded from OT's universal constraint set; see however Bjorkman 2010) for arguments that analyzing the LA system of Nez Perce Crook 1999) requires gradient alignment.

${ }^{8}$ On Hungarian stress, see Hayes (1995 330) with references.

9 DeP-Prom is not strictly necessary in this analysis; it is included to show faithfulness violations incurred by winning candidates in tableaux like (14) and (16) below.

${ }^{10}$ See however Mamet 2011) and Yates 2016a) for possible diachronic explanations.

${ }^{11}$ Hill (2005 473) provides a complete list of unaccented roots.
} 


\begin{tabular}{|c|c|c|c|c|c|c|c|}
\hline \multicolumn{4}{|c|}{$\sqrt{ }$ ACCENTED } & \multicolumn{4}{|c|}{$\sqrt{ }$ UNACCENTED } \\
\hline / $\sqrt{ }$ sá?i/ & 'belly' & / $\sqrt{ }$ náqma/ & 'hear' & $/ \sqrt{ }$ tama $/$ & 'mouth' & $/ \sqrt{ }$ yax $/$ & 'say' \\
\hline / $\sqrt{\text { táxwi/ }}$ & 'body' & / $\sqrt{ }$ nəyú / & 'have' & $/ \sqrt{ } \mathrm{ma} /$ & 'hand' & $/ \sqrt{ }$ təw $/$ & 'see' \\
\hline$/ \sqrt{ }$ șú:n & 'heart' & $/ \sqrt{ }$ híwt $\widehat{t} \mathrm{u} /$ & 'know' & $/ \sqrt{ } \mathrm{ki} /$ & 'house' & $/ \sqrt{ }$ wən/ & 'put in' \\
\hline$/ \sqrt{ }$ xútapi/ & 'bow’ & / $\sqrt{\text { t } \int a ́ n g n ə w / ~}$ & 'be angry' & $/ \sqrt{ }$ təwi/ & 'chest' & $/ \sqrt{ } \max /$ & 'give' \\
\hline$\sqrt{ }$ tóki/ & 'burrow' & / J təwáş/ & 'lose' & & & & \\
\hline
\end{tabular}

The principal diagnostic for a root's accentedness is whether it exhibits fixed or variable stress in connection with certain affixes. For instance, the verbal suffixes in 9 attract stress away from unaccented roots, but accented roots retain stress in combination with these suffixes:

\begin{tabular}{|c|c|c|c|c|c|}
\hline \multicolumn{2}{|c|}{ ACCENTED SUFFIX } & \multicolumn{2}{|c|}{$+\sqrt{ }$ ACCENTED } & \multicolumn{2}{|c|}{$+\sqrt{ }$ UNACCENTED } \\
\hline /-qá/ & (PRS.SG) & [náqma-qa] & 'hear-PRS.SG' & [ya-qá?] & 'say-PRS.SG’ \\
\hline & & [nəyú-qa] & 'have-PRS.SG' & [təw-qá?] & 'see-PRS.SG' \\
\hline /-qál & (PST.IPFV.SG) & [híwt]u-qal] & 'know-PST.IPFV.SG' & : [ya-qál] & 'say-PST.IPFV.SG' \\
\hline & & [tfáynəw-qal] & 'be.angry-PST.IPFV.SG' & । [wən-qál] & 'put.in-PST.IPFV.SG' \\
\hline
\end{tabular}

By analyzing /-qá/ and /-qál/ as accented suffixes, the LM analysis correctly predicts the distribution of stress in 9): accented roots receive stress due to their position to the left of these suffixes, as in (10), but with unaccented roots, these suffixes are the only accented morpheme and so are stressed, as in (11):

(10)

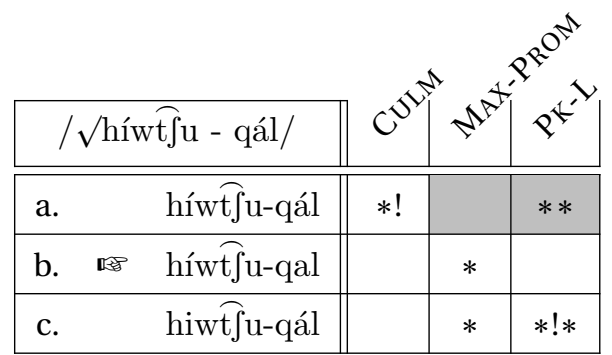

$(11)$

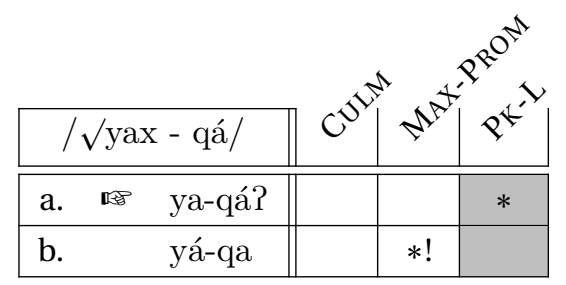

A root's accentedness can also be determined in forms prefixed with any one of a set of agreement prefixes, which mark the person and number of a nominal possessor or verbal subject. (12) shows that stress surfaces on these prefixes when added to unaccented roots, but once again, remains on the root with accented roots.

\begin{tabular}{|c|c|c|c|c|c|}
\hline \multicolumn{2}{|c|}{ PREFIX } & \multicolumn{2}{|c|}{$+\sqrt{ }$ ACCENTED } & \multicolumn{2}{|c|}{$+\sqrt{ }$ UNACCENTED } \\
\hline /nә-/ & (1SG) & [nə-híwt $\left.\int \mathrm{u}\right]$ & '1sG-know' & I [nó-tama] & '1sG-mouth' \\
\hline /ใә-/ & $(2 \mathrm{SG})$ & [?ə-táxwi] & '2sG-body' & [?ว́-yax] & '2sG-say’ \\
\hline /рә-/ & $(3 \mathrm{SG})$ & [pə-t〕ánnəw] & '3sG-be.angry' & [pó-max] & '3sG-give' \\
\hline /tfəm-/ & (1PL) & {$[$ t〕əm-táxwi] } & '1 PL-body' & [tfóm-ki] & '1PL-house' \\
\hline /Pәm-/ & $(2 \mathrm{PL})$ & [Pəm-șú:n] & '2PL-heart' & [Póm-ki] & '2PL-house' \\
\hline /pəm-/ & (3PL) & [pəm-xútapi] & '3PL-bow’ & [pám-təw] & '3PL-see' \\
\hline
\end{tabular}

In contrast to Alderete (2001b) (cf. section 3 below), I analyze the agreement prefixes in 12) as unaccented. Stress therefore falls on a prefixed accented root because it is the only accented morpheme in the word, while prefixal stress emerges with unaccented roots in accordance with the default phonological preference for leftmost stress; illustrative tableau are provided in (13) and (14) respectively: 
(13)

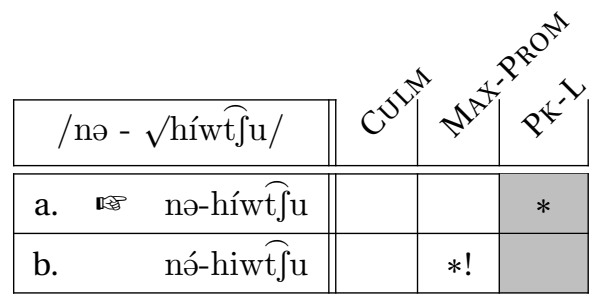

$(14)$

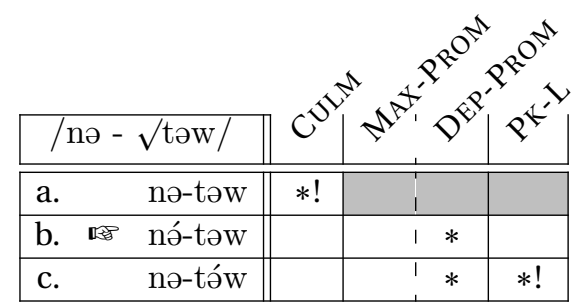

It is important to note that the unaccented roots in (9) and (12) are not unstressed because they cannot be stressed (i.e. stress-rejecting) ${ }^{12}$ Rather, unaccented roots can be assigned stress, receiving default stress when affixed only with unaccented suffixes. In addition, PRE-ACCENTING suffixes (marked /' - /), which place a lexical accent on the syllabic nucleus immediately preceding the affix specified with this feature ${ }^{13}$ may cause stress to surface on an unaccented root. Neither type of suffix has any effect on accented roots, which retain stress on their accented syllable. The distribution of stress with these suffixes is summarized in (15):

\begin{tabular}{|c|c|c|c|c|c|}
\hline \multicolumn{2}{|c|}{ UN/PRE-ACCENT SUFFIX } & \multicolumn{2}{|c|}{$+\sqrt{ }$ ACCENTED } & \multicolumn{2}{|c|}{$+\sqrt{ }$ UNACCENTED } \\
\hline /-wə/ & (PRS.PL) & 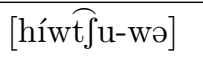 & 'know-PRS.PL & [yáx-wə] & 'say-PRS.PL' \\
\hline /-wənə/ & (CUST.PL) & [təwáș-wənə] & 'lose-CUST.PL' & [máx-wənə] & 'give-CUST.PL' \\
\hline /'- $\mathrm{Paw} /$ & (LOC) & [háxa-Paw] & 'sand-LOC' & [pə-tamá-Paw] & '3SG-mouth-LOC' \\
\hline /'-na/ & (INL) & [tóki-ya] & 'burrow-INL' & I [nə-má-ya] & '1SG-hand-INL' \\
\hline
\end{tabular}

This distribution is also predicted by the constraint ranking already established. The tableau in (16) shows that, when a word contains an initial unaccented root and no other accented morphemes, the unaccented $\operatorname{root}(/ \max /)$ receives default leftmost stress:

\begin{tabular}{|lr||c|c:c|c|}
\hline \multicolumn{2}{|c|}{$/ \sqrt{ } \max -$ wənə/ } & CUlm & MAX-Prom & DEP-Prom & PK-L \\
\hline \hline a. & max-wənə & $* !$ & & & \\
\hline b. & máx-wənə & & & $*$ & \\
\hline c. & max-wónə & & & $*$ & $* !$ \\
\hline
\end{tabular}

Similarly, a preaccenting suffix may induce stress on an unaccented root, as in [17, but when the root is accented, it is stressed by virtue of being the leftmost accented morpheme, as in (18):

(17)

\begin{tabular}{|c|c|c|c|c|}
\hline \multicolumn{2}{|c|}{$/$ pə - $\sqrt{ }$ tama -'?aw/ } & $\omega^{j}$ & 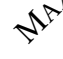 & $Q^{+\prime}$ \\
\hline a. प्रिण & pə-tamá-?aw & & & $* *$ \\
\hline b. & pó-tama-?aw & & $* !$ & \\
\hline c. & pə-tama-?aw & $* !$ & * & \\
\hline
\end{tabular}

(18)

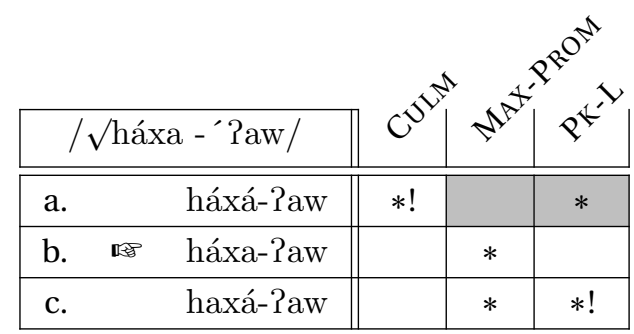

The data laid out above constitutes the core of the Cupeño stress system and, as is clear from the tableaux presented, all can be accounted for by the LM analysis. However, all of this data is also consistent with the RCA analysis. Like LM, the RCA analysis posits left edge default stress to account for $16,{ }^{14}$ while root

12 Revithiadou (1999 46-51) argues that such an accentual feature - termed "unaccentable" — is attested in other LA systems, including Russian, Greek, and Salish.

13 For reasons of space, the formal mechanism by which a lexical accent sponsored by a preaccenting affix affiliates with the preceding syllable is not discussed here. One possibility is that preaccenting morphemes are specified as the tail of a trochaic foot, as in Inkelas (1999) analysis of Turkish "prestressing" suffixes. Note that the pattern of default leftmost stress argued for in this paper is prima facie evidence for trochaic foot structure (rather than iambs, as proposed by Crowhurst 1994 and followed by Alderete 2001b.

${ }^{14}$ On the (more complicated) implementation of default stress under the RCA analysis, see n. 15 below. 
stress in 17, 10), and 18] - the cases in which multiple lexical accents are present in the input - can equally be explained by privileged faithfulness to the accentual properties of roots.

These cases are indicative of a broader problem that arises in comparing the LM and RCA analyses, viz., that their testable predictions are very similar. Because Cupeño has relatively few prefixes, the descriptive generalization that accented roots strongly tend to be stressed can be attributed either to the fact that they are roots or to the fact that they are typically the word's leftmost constituent morpheme. Sections 3,4 therefore examine word stress in two prefixing contexts, where these two properties are independent, and as a consequence, the LM and RCA analyses diverge. Based on the prefixing data, I argue in section 5 that the tendency for roots to be stressed is epiphenomenal, the result of their prosodically preferred linear position at left word edge.

\section{Agreement prefixes \& the LM analysis}

It was proposed in 2.2 that the agreement prefixes in 12 - 1SG /nə-/, 3SG / pə-/, etc. — are lexically unaccented morphemes. Under the LM analysis, these prefixes are assigned default leftmost stress when added to unaccented roots, but are unstressed when added to accented roots because the lexical accent of the root attracts stress. In contrast, Alderete 2001b) analyzes these prefixes as accented morphemes (i.e. “/nó-/", “/pá-/", etc.). This analysis has significant implications for assessing the principles of stress assignment operative in examples like [nə-híwt $\left.\int u\right]$ in 13) and [pə-tamá-?aw] in 17). The former would require that the accent of the root dominates the accent of the prefix to its left, while the latter would show that, when multiple lexical accents are present, it is the rightmost that "wins" (i.e. bears stress).

Both of these patterns can be captured under the RCA analysis ${ }^{15}$ but neither is compatible with the LM analysis, which would predict that accentual resolution proceeds in exactly the opposite way, yielding unattested *[nó-hiwt $\left.\int u\right]$ and *[pó-tama-Paw]. In remainder of this section, however, it is demonstrated that neither of these patterns withstands scrutiny: 3.1 shows that there is no positive evidence that the agreement prefixes are accented, while 3.2 presents direct counter-evidence to the alleged "rightmost wins" pattern, and in turn, argues that the agreement prefixes are unaccented.

3.1 Agreement prefixes are not accented According to the RCA analysis, evidence for the accentedness of the subject/possessor agreement prefixes comes from words containing what Alderete (2001b) refers to as "object markers," a set of morphemes that function to mark the direct or indirect object of a transitive verb and linearly precede both these agreement prefixes and the verbal root. These "markers" - given in (19) - are never stressed, including when attached to a prefixed unaccented root, as in (201-c), or to a bare unaccented root, as in 20 $\mathrm{d}-\mathrm{f}$ ):

\begin{tabular}{l|ll} 
& SG & PL \\
\hline 1 & {$[$ ni $]$} & {$[$ trimi $]$} \\
2 & {$[$ ?i $]$} & {$[$ ?imi $]$} \\
3 & {$[\mathrm{pi}]$} & {$[\mathrm{mi}]$}
\end{tabular}

\begin{tabular}{|c|c|c|c|c|}
\hline \multicolumn{3}{|c|}{ OBJ + AGR + $\sqrt{ }$ UNACCENTED } & \multicolumn{2}{|c|}{ OBJ $+\sqrt{ }$ UNACCENTED } \\
\hline a. & [?i=póP-max] & '2SG.O=3PL-give' & d. $\quad[\mathrm{mi}=$ máx-wənə] & '3PL.O=give-CUST.PL \\
\hline b. & [mi=ná-təw $]$ & '3PL.O=1SG-see' & [mi=tó-wə] & '3PL.O-see' \\
\hline c. & {$\left[\mathrm{mi}=\overparen{\left.\mathrm{t} \int \partial ́ \mathrm{~m}-\mathrm{t} \partial \mathrm{w}\right]}\right.$} & '3PL.O=1PL-see' & [ni=yáx $]$ & ‘1sG.o-say’ \\
\hline
\end{tabular}

Alderete (2001b) argues that examples like 20 $\mathrm{a}-\mathrm{c}$ ) show that the agreement prefixes are accented, since they appear to attract stress in preference to the "object markers," which would otherwise receive default

\footnotetext{
${ }^{15}$ To reconcile the phonological preference for leftmost stress that is independently necessary under the RCA analysis with this "rightmost accented affix wins" pattern, Alderete 2001b assumes that Cupeño has a default-to-opposite stress system (cf. Crowhurst 1994, with conflicting directionality at different levels of metrical structure: stress peaks (heads of $\omega$ ) are preferentially right-aligned, but stress prominences (heads of $\Sigma$ ) left-aligned (see Baković 1998 i.a.). Under this analysis, words with leftmost default stress have only a stress prominence (i.e. no stress peak), although this analytic distinction has no impact on the phonetic realization of stress in Cupeño.
} 
leftmost stress. This analysis assumes, however, that these "markers" are stressable affixes, a hypothesis that is problematized by examples like $(20 \mathrm{~d}-\mathrm{f})$, where they attach instead to an unprefixed unaccented root. In such cases, analyzing the "object markers" as affixes wrongly predicts that they will be assigned default leftmost stress, which instead falls on the unaccented root.

The stress pattern in (20d-f) thus strongly suggests that the "object markers" are instead clitics (e.g.) "free clitics" (in the sense of Selkirk 1996), which stand outside the word-level stress domain — as argued by Hill 2005 111-4) on morphosyntactic grounds. A direct consequence of this analysis is that examples like $(20 \mathrm{a}-\mathrm{c})$ provide no positive evidence that the agreement prefixes are accented: stress will fall on the prefix whether it is accented (per Alderete 2001b) or unaccented, as proposed in section 2.2 above. The tableau in 21 shows that the LM analysis correctly generates the attested stress patterns in $20 \mathrm{a}-\mathrm{c})$ under the assumption that the agreement prefixes are unaccented:

\begin{tabular}{|c|c|c|c|c|c|}
\hline \multicolumn{2}{|c|}{$/ \mathrm{mi}=$ nə $-\sqrt{ }$ təw $/$} & CulM & MAX-PROM & DEP-PROM & PK-L \\
\hline a. & $\mathrm{mi}=\mathrm{n} \partial-\mathrm{t} \partial \mathrm{w}$ & $* !$ & & & \\
\hline b. & mí=nə-təw & $* !$ & & * & $*$ \\
\hline c. $\quad$ 吗 & $\mathrm{mi}=$ nə́-təw & & & $*$ & \\
\hline d. & $\mathrm{mi}=$ nə-táw & & & $*$ & $* !$ \\
\hline
\end{tabular}

This assumption is defended explicitly in 3.2 below, where evidence is adduced against the "rightmost accent wins" pattern hypothesized by Alderete (2001b); this finding in turn will necessitate that the agreement prefixes be analyzed as unaccented.

3.2 Against "rightmost wins" The elimination of all positive evidence for the accentedness of the subject/possessor agreement prefixes also effectively eliminates all support for Alderetes (2001b) claim that, when a word contains multiple accented affixes, stress falls on the rightmost. The principal evidence for this claim comes from unaccented roots (e.g. $/ \sqrt{ }$ yax $/, / \sqrt{ }$ tama $/$ ) that are both prefixed with one of the agreement markers discussed in 3.1 and also suffixed with an accented or preaccenting suffix (/-qál/, /-'?aw/) — thus, for instance, [pə-ya-qál] and [pə-tamá-Paw] (cf. 17) above), where stress is assigned to the accent associated with these suffixes in preference to the prefixes to their left ${ }^{16}$ Yet such cases reflect "rightmost wins" only if the agreement prefixes are accented, a hypothesis for which there is no independent support (cf. 3.1 above). If these prefixes are instead unaccented, examples like [pə-ya-qál] and [pə-tamá-?aw] simply show stress predictably falling on a word's single accented morpheme.

The latter hypothesis is recommended by evidence for the opposite pattern of affixal accent resolution, i.e. "leftmost wins." Words containing multiple accented and/or preaccenting suffixes are relatively rare, but there are at least a few clear examples in which two preaccenting suffixes occur, /' -ya/ and /'-Paw/ 17 When these suffixes combine with an accented root (e.g. / $\sqrt{ }$ sówə(-t)/ 'rattlesnake'), the root retains stress: [sáwə-t-ya-Paw] 'rattlesnake-ABSL-INL-LOC'. Yet when they combine with an unaccented root (e.g. /towi/ 'chest'), it is the lexical accent sponsored by the leftmost of the two preaccenting suffixes that attracts stress: [nə-təwí-ya-Paw] '1sG-chest-INL-LOC'. This "leftmost wins” pattern of affixal accent resolution is predicted by the LM analysis, as evident in the tableau in 22) 18

16 Alderete 2001b argues that the accented suffix /-qalí/ (DS.SG) - which is assigned stress when added to unaccented roots, e.g. [ya-qalí] 'say-DS.SG' - is composed of /-qál/ (PST.IPFV.SG) + an accented suffix "/-í/" and therefore also shows "rightmost wins." However, this morphological segmentation cannot be (synchronically) correct, since it would wrongly predict that the corresponding plural suffix /-wəni/ (DS.PL) should bear a lexical accent (i.e. "/-wəní/) and so attract final stress in combination with unaccented roots, e.g. *[yax-wəní] instead of [yáxwəni]. See further Hill (2005 406-12) for analysis of these suffixes as switch-reference markers and discussion of their historical background.

${ }^{17}$ The combination is discussed by Hill 2005 27, 189-91) as a preaccenting locative suffix /' - yaPaw/, but given that all other preaccenting suffixes are monosyllabic, it seems formally attractive (and semantically unproblematic) to analyze it as a composite of /' -ya/ and /'-

${ }^{18}$ More evidence for stress assignment to the leftmost of multiple accented affixes may come from words containing what Alderete 2001b 481-3) refers to as the "nominalizer suffix" /-í/, which is stressed in preference to accented 
(22)

\begin{tabular}{|c|c|c|c|c|}
\hline \multicolumn{2}{|c|}{ 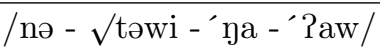 } & Culm & MAX-PROM & PK-L \\
\hline a. & nə-təwí-ya-?aw & & * & $* *$ \\
\hline b. & nə-təwi-yá-?aw & & * & $* * *$ ! \\
\hline c. & nó-təwi-ya-?aw & & $* * !$ & \\
\hline
\end{tabular}

If the proposed analysis of 22] is correct, it follows naturally that the agreement prefixes must be unaccented (per 2.2 above:). For instance, [pə-ya-qál] cannot contain an accented prefix, since such a prefix would be stressed in preference to an accented suffix to its right in accordance with the established "leftmost wins" pattern (yielding *[pó-ya-qal]). Similarly, the expected form for 22] would be *[nó-təwiya-?aw] rather than attested [nə-təwí-ya-?aw].

3.3 Local summary: agreement prefixes and their implications It was argued in 3.1 that the subject/possessor agreement prefixes need not be analyzed as accented, and in 3.2. that these prefixes are in fact unaccented. This result undercuts the primary evidence held to support RCA (against LM), which comes from prefixed forms like [nə-híwt $\left.\int \mathrm{u}\right]$ in $[13$ that putatively show root accent winning over the accented prefix to its left. Such examples are better understood as cases in which stress is assigned to the word's single accented morpheme $\left(/\right.$ nə- $\sqrt{ }$ híwt $\left.\int \mathrm{u} /\right)$ and therefore consistent with the LM analysis, just as the rest of the data examined in sections 1,2 above.

Nevertheless, none of this data directly contradicts the central claim of the RCA analysis, viz., that the accentual properties of roots are privileged over those of affixes. I challenge this claim in section 4 below, arguing that Cupeño partial reduplication provides evidence that an accented affix attracts stress in preference to an accented root to its right. This pattern is predicted by the LM analysis, but runs counter to the RCA analysis.

\section{Reduplication \& the LM analysis}

Cupeño has several different reduplicative processes described by Hill 2005). This section focuses on the type that is traditionally analyzed as $C V$-prefixing reduplication, which has grammatical functions that include aspectual modification in verbs and pluralization in adjectives and nouns. The prefixed $C V$ reduplicant is consistently stressed and induces syncope of the first syllable of the root whenever the result would be phonotactically licit; ${ }^{19}$ thus syncope does not (e.g.) create complex syllable margins, which are unattested in the native lexicon and repaired by epenthesis in other affixal contexts (cf. Hill |2005|20, 2930). Examples of reduplication with and without syncope are given in 23) and (24) respectively:

$$
\begin{aligned}
& \text { a. míxəl 'custom' : mímxəl 'customs' } \\
& \text { b. Pawólßə 'grown-up.sG' : PáPwəlßə 'grown-up.PL' } \\
& \text { a. hélii 'wide.SG' : héhelîi 'wide.PL' } \\
& \text { b. túlnikif 'black.sG' : tútulnikif 'black.PL' }
\end{aligned}
$$

The fact that the reduplicant consistently bears stress falsifies the otherwise sound descriptive generalization that in Cupeño lexically accented roots are always stressed on their accented syllable. This generalization underpins the RCA analysis, which encounters problems, in particular, with examples like 23b) and 24, where an accented root syllable has a correspondent in the output but is nevertheless

suffixes to its right. To handle its "special" phonology, Alderete posits a morpheme-specific constraint STRESSTO-í that requires stress to fall on this suffix (but is dominated by root faithfulness). No additional stipulation is needed to account for this pattern under the LM analysis, which predicts "leftmost wins" in affixal accent resolution. However, the complex morphophonology of the "nominalizer" is discussed (under the traditional label " $i$-ablaut") by Hill 2005 42-6), who argues against analyzing it as an independent suffix.

${ }^{19}$ Alternatively, Cupeño partial reduplication can be analyzed as an infixing operation, and the reduplicative morpheme as preaccenting; see Haynes 2007) and Yates (2017). 
unstressed ${ }^{20}$ To account for these apparently exceptional stress patterns, the RCA analysis would be forced to introduce additional machinery - (e.g.) a constraint STRESS-TO-RED (cf. n. 18) — and thereby run the risk of stipulation.

A more economical approach is to assume that the reduplicative morpheme itself is lexically accented, i.e. /RÉD/. This feature can be seen most clearly in reduplicated forms of unaccented roots, e.g. [pə-yá-yax] '3sG-RED-say' (/ $\sqrt{ }$ aax / 'say'); such forms exhibit non-default stress, thereby implying that partial reduplication introduces a lexical accent into the input, and more specifically, are stressed on the reduplicant, whose stress-attracting behavior is thus exactly parallel to that of other accented morphemes. This analysis of [pə-yá-yax] is schematized in the tableau [25:

\begin{tabular}{|lr||c|c|c|}
\hline \multicolumn{2}{|c|}{$/$ pə - RÉD - ل yax/ } & CULM & MAX-Prom & PK-L \\
\hline \hline a. & pə-yá-yax & & & $*$ \\
\hline b. & pá-ya-yax & & $* !$ & \\
\hline
\end{tabular}

25) shows that the LM analysis correctly generates stress in reduplicated forms of unaccented roots; note that candidate (b) would be preferred under either RCA or LM if the input contained no lexically accented morpheme.

Still more significantly, the pattern of consistent reduplicant stress observed in (23p) and (24) falls out straightforwardly under the LM analysis: the accented reduplicative morpheme is stressed because it is closer to the left edge of the word than the accented root, and so better satisfies PK-L. An illustrative tableau for 23p) is given in (26):

\begin{tabular}{|c|c|c|c|c|}
\hline \multicolumn{2}{|c|}{ /RÉD - V Pawólßə/ } & Culm & MAX-PROM & PK-L \\
\hline a. & PáPwə́lßə & $* !$ & & * \\
\hline b. $\quad \square$ & ใá?wəlßə & & * & \\
\hline c. & Påwólßə & & $*$ & $* !$ \\
\hline
\end{tabular}

In contrast, the stress pattern in 26 cannot be generated under the (unmodified) RCA analysis, which incorrectly predicts that candidate (c) - with stress surfacing faithfully on the lexical accent of the root would be the winner.

Partial reduplication therefore constitutes a clear case in which the LM and RCA analyses make different empirical predictions. Since few such cases exist in Cupeño, it is non-trivial that only the LM analysis explains the distribution of word stress in reduplicated forms.

\section{Conclusions \& discussion}

The preceding sections have demonstrated that the distribution of word stress in Cupeño can be derived from the interaction of the lexically specified accentual properties of morphemes (accented, unaccented, preaccenting) and the purely phonological preference that stress should coincide with the left edge of the word. This preference is optimally satisfied in the absence of accented/preaccenting morphemes, which attract stress away from the word's left edge due to high-ranking constraints requiring faithfulness to underlying prominence. If several such morphemes are present in the input, stress is assigned to the leftmost because it best satisfies this phonological preference while (i) incurring minimal faithfulness violations and (ii) fulfilling the necessary condition that every word has one (and only one) stressed syllable. These properties are implemented in an optimality-theoretic framework under the LM analysis, which then correctly predicts word stress in the data examined.

\footnotetext{
${ }^{20}$ Under an infixing analysis of reduplication (Yates 2017 cf. n. 19 above), only examples like 23p) with second syllable root accent are problematic for the RCA analysis, since 24) would then show stress realized faithfully on the (first syllable) root accent. The (descriptive) stress shift observed between base and reduplicated form in 23b) is also problematic for Haynes 2007) infixing analysis, which assumes that infixation of the reduplicant after the lexically accented root syllable is motivated by avoidance of precisely this kind of stress shift.
} 
5.1 LM vs. RCA in Cupeño Compared to Alderete's (2001b) RCA analysis of Cupeño stress, the LM analysis advanced here attains greater empirical coverage, not only handling the core data considered in 2.2. but also accounting for word stress in the reduplicated forms discussed in 4 In dealing with this data, the LM analysis is also more economical than the RCA analysis: both posit a phonological preference for left edge stress (realized in default word-initial stress), but the RCA analysis requires the further supposition that faithfulness relations to the accentual properties of roots are privileged with respect to affixes, an assumption for which there is no positive evidence in Cupeño (cf. 3.3 above).

5.2 Cupeño stress in typological perspective Under the LM analysis, the word-prosodic system of Cupeño is typologically unexceptional among languages with LA systems. The left edge-oriented, default-to-same stress pattern found in Cupeño has an exact analogue in Kiparsky \& Halle's (1977) "Basic Accentuation Principle," which governs stress assignment in a number of Indo-European languages, both ancient (Vedic Sanskrit, Ancient Greek, Hittite) and modern (Modern Greek, Russian) (cf. Kiparsky|2010. Yates 2016b.

Cupeño differs from these IE languages (and others, like Japanese), however, in lacking morphemes that can "override" the accentual properties of the stem to which they attach, a property that Kiparsky \& Halle (1977) refer to as "dominance.'21 Among languages with LA, then, Cupeño's word-prosodic system is relatively simple, having only the canonical features of systems of this type: (i) stress-attracting morphemes (i.e. accented, pre-accenting); and (ii) purely phonological principles that determine which of several accented morpheme will bear stress, or in their absence, assign default stress to a prosodically optimal position. The Cupeño system is therefore broadly comparable to LA systems like Pashto or Spanish in having only properties (i) and (ii) (i.e. no "dominance" effects) ${ }^{22}$ although the extent to which word stress is determined by the idiosyncratic lexical properties of morphemes (especially roots) is greater in Cupeño than in either of these languages.

5.3 Toward a restrictive typology of lexical accent It was pointed out in 2.2 that the predictions of the LM and RCA analyses generally converge because in Cupeño the left edge of the root frequently coincides with the left edge of the word, a context in which the strong tendency for accented roots to attract stress can be plausibly attributed to privileged root faithfulness or to their linear position at the word's left edge. The same is true for Tokyo Japanese and for Russian, the two principal case studies besides Cupeño treated by Alderete (1999 2001a) in his cross-linguistic study of LA systems. Alderete proposes extending the RCA analysis to word stress in these languages, but acknowledges that both can equally be analyzed in terms of a phonological preference for edge-oriented stress ${ }^{23}$ Cupeño therefore constitutes Alderete's strongest case for RCA in LA systems, since under his analysis, only it requires privileged faithfulness to the accentual properties of roots over affixes.

The principal argument advanced in this paper is that there is no need to assume privileged root faithfulness to account for the distribution of word stress in Cupeño. These facts are better explained by the LM analysis, which makes no reference to the morphological distinction between roots and affixes, instead appealing only to the type of phonological principles that are cross-linguistically well-established features of LA systems and of fixed stress systems.

Reanalysis of Cupeño stress in these terms potentially has significant implications for the typology of LA systems. Without positive evidence from Cupeño, it is not clear that there are any languages in which root faithfulness affects stress assignment. At present, it remains uncertain why this typological gap should exist; without empirical support, however, there is reason to suspect that root faithfulness regardless of its status in other phonological domains - nevertheless plays no role in the computation of word stress.

\footnotetext{
21 Kiparsky \& Halle (1977) view dominance as a lexically idiosyncratic property of (mostly derivational) morphemes, and allow for its cyclic re-application in a word's derivation. In contrast, Revithiadou (1999) views cyclicity as unnecessary, and argues that dominance effects in LA systems arise as a consequence of morphological headedness - specifically, of privileged faithfulness to the accentual properties of morphological heads. However they are analyzed, it is clear that such "dominance" effects are attested in some LA systems, although not in Cupeño.

${ }^{22}$ On Pashto stress, see Revithiadou (1999 17-8) with references.

${ }^{23}$ Per Alderete 2001b 494): "Russian and Japanese... show a preference for suffixing morphology, which allows them to be analyzed either as root-controlled accent systems, or in terms of directionality."
} 


\section{References}

Alderete, John D. (1999). Morphologically Governed Accent in Optimality Theory. Ph.D. thesis, University of Massachusetts, Amherst.

Alderete, John D. (2001a). Morphologically Governed Accent in Optimality Theory. Routledge, New York.

Alderete, John D. (2001b). Root-Controlled Accent in Cupeño. Natural Language \& Linguistic Theory 19:3, 455-502.

Baković, Erik (1998). Unbounded Stress and Factorial Typology. Artstein, R. \& M. Holler (eds.), Rutgers Working Papers in Linguistics, vol. 1, 15-28.

Beckman, Jill N. (1998). Positional Faithfulness. Ph.D. thesis, University of Massachusetts, Amherst.

Bjorkman, Bronwyn M. (2010). Morphology and stress in Nez Perce verbs. University of British Columbia Working Papers in Linguistics 29: Proceedings of Workshop on the Structure and Constituency of the Languages of the Americas 15, 70-84.

Crook, Harold D. (1999). The Phonology and Morphology of Nez Perce Stress. Ph.D. thesis, University of California, Los Angeles.

Crowhurst, Megan T. (1994). Foot Extrametricality and Template Mapping in Cupeño. Natural Language \& Linguistic Theory 12:2, 177-201.

Golla, Victor (2011). California Indian Languages. University of California Press, Berkeley.

Hayes, Bruce (1995). Metrical Stress Theory. University of Chicago Press, Chicago / London.

Haynes, Erin Flynn (2007). An Explanation of Base TETU Effects in Kwak'wala and Cupeño. Proceedings of the 33rd Annual Meeting of the Berkeley Linguistics Society, 191-202.

Hill, Jane H. (2005). A Grammar of Cupeño. University of California Press, Los Angeles / Berkeley, CA.

Hill, Jane H. \& Kenneth C. Hill (1968). Stress in the Cupan (Uto-Aztecan) Languages. International Journal of American Linguistics 34:4, 233-241.

Hill, Jane H. \& Rosinda Nolasquez (1973). Mulu'wetam: The First People. Malki Museum Press, Banning, CA.

van der Hulst, Harry (2014). The study of word accent and stress: Past, present, and future. Van der Hulst, Harry (ed.), Word Stress: Theoretical and Typological Issues, Cambridge University Press, Cambridge, UK / New York, 3-55.

Hyman, Larry (2006). Word prosodic typology. Phonology 2, 225-257.

Inkelas, Sharon (1999). Exceptional Stress-Attractic Suffixes in Turkish: Representation vs. the Grammar. Kager, René, Harry van der Hulst \& Wim Zonneveld (eds.), The Prosody-Morphology Interface, Cambridge University Press, Cambridge / New York, 134-187.

Ito, Junko \& Armin Mester (2016). Unaccentedness in Japanese. Linguistic Inquiry 47:3, 471-526.

Kiparsky, Paul (2010). Compositional vs. Paradigmatic Approaches to Accent and Ablaut. Jamison, Stephanie W., H. Craig Melchert \& Brent Vine (eds.), Proceedings of the 21st Annual UCLA Indo-European Conference, Los Angeles, October 30-31, 2009, Hempen, Bremen, 137-181.

Kiparsky, Paul \& Morris Halle (1977). Towards a Reconstruction of the Indo-European Accent. Hyman, Larry (ed.), Studies in Stress and Accent, University of Southern California Press, Los Angeles, 209-238.

Mamet, Ingo (2011). Cupeño stress shift: Diachronic perspectives. International Journal of American Linguistics 77:2, $247-283$.

McCarthy, John \& Alan Prince (1995). Faithfulness and reduplicative identity. Beckman, Jill N., Laura W. Dickey \& Suzanne Urbanczyk (eds.), University of Massachusetts Occasional Papers 18: Papers in Optimality Theory, University of Massachusetts, 249-384.

McCarthy, John \& Alan Prince (1999). Faithfulness and Identity in Prosodic Morphology. Kager, René, Harry van der Hulst \& Wim Zonneveld (eds.), The Prosody-Morphology Interface, Cambridge University Press, Cambridge / New York, 218-309.

McCarthy, John J. (2003). OT constraints are categorical. Phonology 20:1, 75-138.

Prince, Alan \& Paul Smolensky (1993/2004). Optimality Theory: Constraint Interaction in Generative Grammar. Blackwell, Oxford / Malden, MA.

Revithiadou, Anthoula (1999). Headmost Accent Wins: Head Dominance and Ideal Prosodic Form in Lexical Accent Systems. Ph.D. thesis, Leiden University.

Selkirk, Elisabeth (1996). The Prosodic Structure of Function Words. Morgan, James L. \& Katherine Demuth (eds.), Signal to Syntax: Bootstrapping from Speech to Grammar in Early Acquisition, Lawrence Erlbaum Associates, Mahwah, NJ, 187-214.

Yates, Anthony D. (2016a). On the Evolution of Lexical Accent in Cupeño. Paper presented at the 2016 Annual Meeting of the Society for the Study of the Indigenous Languages of the Americas, Washington, D.C., 9 January 2016 (Handout available at: http://www.adyates.com/research).

Yates, Anthony D. (2016b). Stress assignment in Hittite and Proto-Indo-European. Proceedings of the Linguistic Society of America 1, 25/1-15.

Yates, Anthony D. (2017). On reduplication and stress in Cupeño. Paper presented at the 43rd Annual Meeting of the Berkeley Linguistics Society, Berkeley, CA, 4 February 2017 (Slides available at: http://www.adyates.com/research). 